\title{
ArcheoSciences
}

Revue d'archéométrie

33 (suppl.) | 2009

Mémoire du sol, espace des hommes

\section{Magnetic surveys of Early and Middle Neolithic settlements in Austria}

Klaus Löcker, Erich Nau, Wolfgang Neubauer and Alois Hinterleitner

\section{(2) OpenEdition}

1 Journals

Electronic version

URL: https://journals.openedition.org/archeosciences/1365

DOI: 10.4000/archeosciences. 1365

ISBN: 978-2-7535-1599-4

ISSN: 2104-3728

Publisher

Presses universitaires de Rennes

Printed version

Date of publication: 30 October 2009

Number of pages: 101-104

ISBN: 978-2-7535-0943-6

ISSN: $1960-1360$

\section{Electronic reference}

Klaus Löcker, Erich Nau, Wolfgang Neubauer and Alois Hinterleitner, "Magnetic surveys of Early and

Middle Neolithic settlements in Austria", ArcheoSciences [Online], 33 (suppl.) | 2009, Online since 30

October 2011, connection on 01 February 2022. URL: http://journals.openedition.org/archeosciences/ 1365 ; DOI: https://doi.org/10.4000/archeosciences.1365 


\title{
Magnetic surveys of Early and Middle Neolithic settlements in Austria
}

\author{
Klaus LöCKer ${ }^{* *}$, Erich NaU*, W. Neubauer ${ }^{*}$ and Alois Hinterleitner ${ }^{* *}$
}

Key words: Neolithic settlements, Magnetic prospection, GIS, Archaeological interpretation.

\section{INTRODUCTION}

Archaeological prospection has become more important during the last few decades because of technical developments in hard- and software. Magnetic prospecting using high resolution multisensor caesium-gradiometer systems with sensitivities of $0.005 \mathrm{nT}$ is used for detailed mapping of sites detected by aerial archaeology. The instrumentation makes it possible to measure up to $1 \mathrm{ha} / \mathrm{h}$ with a resolution of $0.5 \times 0.125 \mathrm{~m}$. All prospection data are integrated into a GIS which provides the functionality for the combined interpretation of the different data. Case studies from Austrian Early and Middle Neolithic sites and the landscape they are situated in are presented to illustrate the aspects of archaeological interpretation of complex prospection data. We also present some virtual reality approaches to present and explore the interpretation models.

\section{Early Neolithic SETtLements}

The Early Neolithic in Austria (4500/4300-4950/4900 $\mathrm{BC})$ is represented by the Linearband Culture. The respective settlements are located mainly in the north and east of Austria. Large open and fortified settlements covering up to 20 ha have been found by systematic aerial photography all around eastern parts of Austria. Until 1991 magnetic prospection became the main method for the systematic evaluation of these monuments.

Asparn a.d. Zaya is a well known settlement from the Early Neolithic situated on loess soil with low susceptibility. The site covering 25 ha was magnetically prospected during the 1990's. The surveys recovered typical remains of the Neolithic longhouses. Even the traces of single posts were resolved by the magnetic surveys, at that time done with a resolution of $0.1 \mathrm{nT}$. The archaeological analysis of the magnetic evidence shows at least three periods of occupation. Two of them were fortified by 4-6 $\mathrm{m}$ wide ditches which partly have been up to $3 \mathrm{~m}$ in depth. The magnetic evidence shows various amounts of damage by erosion invoked by the intensive agricultural use of the site. According to calibrated radiocarbon dates the occupation of the site dramatically ended approx. $4950 \mathrm{BC}$ by a massacre. The remains of the killed inhabitants were found at the bottom of the ditches. Occasionally a later settlement from the germanic period (200-400 AD) was detected at the lowest terrace of the river Zaya respecting the former Neolithic site.

Grossrussbach-Weinsteig (Fig. 1) is one of the largest fortified Early Neolithic settlements in Middle Europe detected by aerial archaeology so far. The rectangular fortification ditch is approx. $800 \mathrm{~m}$ long and $350 \mathrm{~m}$ wide enclosing 21 ha. The prospection reveals a huge, rectangu-

\footnotetext{
*Vienna Institute for Archaeological Science, University of Vienna, Franz Klein-Gasse 1/V, A-1190 Vienna, Austria. (wolfgang.neubauer@univie. ac.at)

** Central Institute for Meteorology and Geodynamics, Hohe Warte 38, A-1190 Vienna, Austria
} 


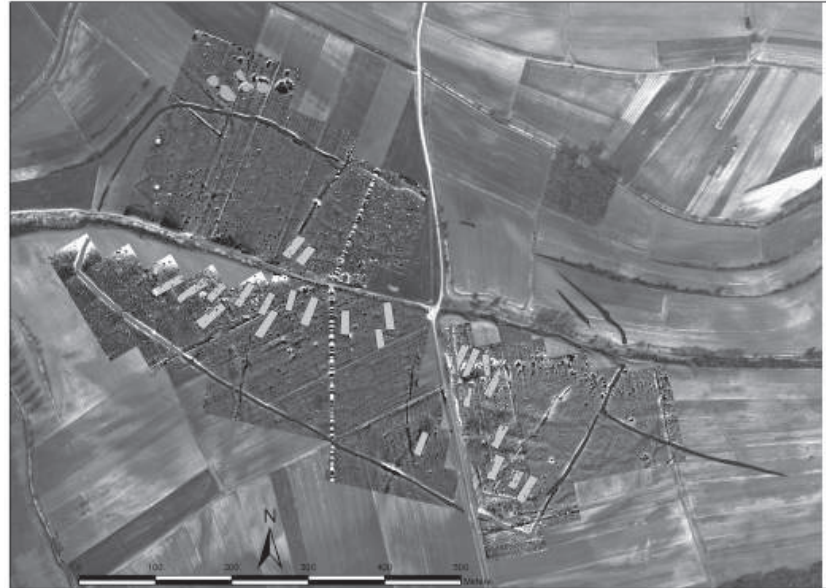

Figure 1 (see color plate): Orthophotograph of the Early Neolithic settlement Grossrussbach-Weinsteig combined with magnetograms and the archaeological interpretation.

lar enclosure, formed by a fortification ditch 3 to 4 meters wide. An entrance, formed by a $4.5 \mathrm{~m}$ wide interruption in the ditch was detected in the southwest. The magnetogram shows no anomalies indicating a probable wooden gate. This might be also due to the high amount of erosion obvious in the aerial photos as well as in the magnetograms indicating the bad state of preservation of this large site. We carried out a small excavation in the southwest near the entrance to verify the $3 \mathrm{D}$ magnetic modelling of the ditch, for detailed measurements of magnetic susceptibility and for the verification of the dating of the monumental site. The finds, mainly ceramics, date the fortification back to the early Neolithic.
Breiteneich is located in basin of Horn densely occupied during the Early and Middle Neolithic period. This landscape was systematically prospected over the last years. This site is presented as a case study, documenting the latest state-of-the-art in large scale magnetic prospecting with a wheeled 6-sensor Caesium-magnetometer. A high resolution DTM of the site was produced using the latest terrestrial laser scanning technology. This allows us to virtually present the prospection data and the archaeological interpretation of the settlement formed by many longhouses in the landscape they are situated in.

\section{Middle Neolithic settlements}

In the Middle Neolithic period (4900/4850 - 4300 BC) the Lengyel Culture spread into the eastern part of Austria. It is well known for its monumental circular ditch systems, the oldest Middle European monuments. Large systematic magnetic surveys of all known circular ditch systems have been carried out to situate these monuments in the landscape and to investigate the settlements they are situated in. In the first phase of the Lengyel Culture (4900 - 4550/4500 $\mathrm{BC})$ the settlements have not been fortified and are always including a circular ditch system. The second phase is represented by large fortified settlements often erected in optimal strategic topographical situations (Fig. 2).

Wetzleinsdorf, a fortified settlement from the Middle Neolithic became first known due to a clay mine close by, which partly destroyed the site. The settlement is located just about $900 \mathrm{~m}$ from the circular ditch system of Karnabrunn. Within the last years an area of about 12 ha could be prospected using magnetic devices, but still the total area of the settlement could not be determined. The surveys show the

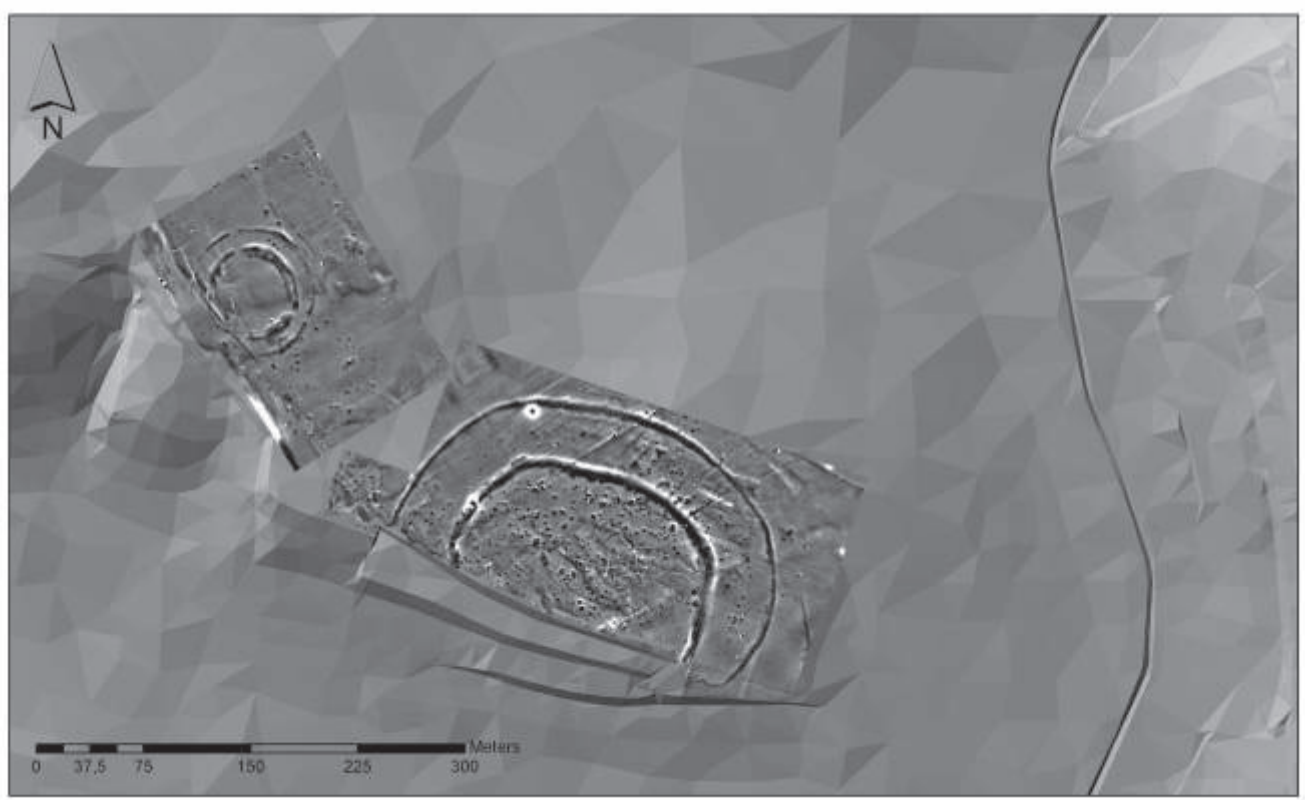

Figure 2: Digital terrain model of Porrau combined with magnetic survey data. 
remains of a partly destroyed oval fortification ditch, 240 $\mathrm{m}$ long and at least $120 \mathrm{~m}$ wide. Various other remains of the settlement, houses, pits and even single posts could be recovered. Parts of them are situated outside the fortification ditch, showing at least two periods of occupation.

At the site of Porrau (Fig. 2) magnetic surveys were started to locate the Middle Neolithic circular ditch system. Right beside the monument a fortified settlement was located 200 $\mathrm{m}$ in the southeast of this monument. The settlement is characterized by two $4-7 \mathrm{~m}$ wide fortification ditches, both limited by to the west by a $10 \mathrm{~m}$ cliff. The oval ditch systems enclose a densely occupied area of 1.5 ha and 3.3 ha respectively, representing two periods of occupation. Two periods of use could also be detected at the circular ditch system. According to surface finds the fortification is dating to the second phase of the Lengyel culture.

Kleinrötz (Fig. 3) is a well known Middle Neolithic circular ditch systems, magnetically surveyed since 1997 . The extended surveys revealed the large corresponding settlement area during the last years. Remains of the Middle Neolithic settlement are situated southeast of the monumental circular ditch system. Surface finds collected during the magnetic survey confirm this date. The anomalies in this area can be interpreted as pits, small ditches and posts, representing the remains of typical Middle Neolithic houses, 20 to $50 \mathrm{~m}$ long and up to $10 \mathrm{~m}$ wide. Smaller houses can be interpreted due to the arrangement of the posts. It is likely that the settlement was partly destroyed during the time Hallstatt period, when a large cemetery with burial mounds was erected around the circular ditch system. Comparing the surveys carried out in 1997 and the latest ones, an ongoing destruction of the site through agricultural use and erosion is obvious.

In the north and east of the Middle Neolithic circular ditch system of Steinabrunn a settlement area of the same period could be detected. The anomalies of rectangular and rounded pits, postholes and ditches could be recovered, which can be interpreted as remains of houses. To confirm the prospection data and its archaeological interpretation a stratigraphic excavation was carried out in 2005. Based on the prospection results and the primary excavations a first virtual reality reconstruction of the site gives an insight in a Middle Neolithic micro region and the circular ditch system with its surrounding settlement.
Figure 3: Kleinrötz, aerial photograph combined with the archaeological interpretation of magnetic survey data.

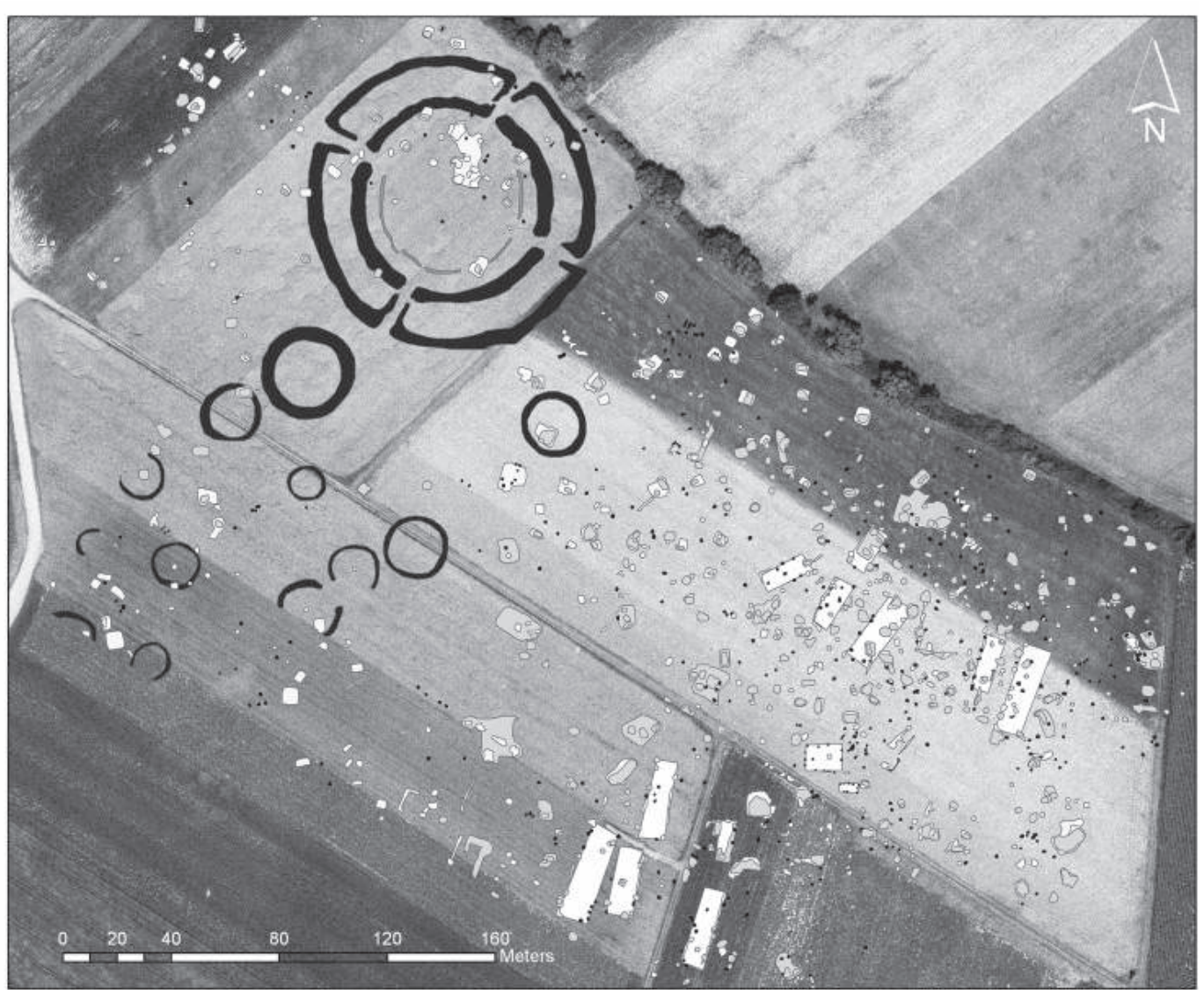




\section{References}

Eder-Hinterleitner, A., Neubauer, W. and Melichar, P., 1999. Magnetic modelling for the 3D reconstruction of the neolithic circular ditch system of Steinabrunn/Austria. In Faßbinder, J., Irlinger, W., Archaeological Prospection, Arbeitshefte des Bayerischen Landesamtes für Denkmalpflege 108, 32-33.

Doneus, M., Neubauer, W. and Trnka, G., 2001. Das jüngerlinearbandkeramische Grabenwerk von Großrußbach-Weinsteig in Niederösterreich - das größte Erdwerk der Linearbandkeramik? Prehistoria Alpina, 37: 13-26.
Neubauer, W., Doneus, M., Eder-Hinterleitner, A. and LöCKER, K., 2003. The Early Neolithic enclosure WeinsteigGrossrussbach. Archaeologia Polona, 41: 236-238.

Fera, M., Neubauer, W. and Rachbauer, O., 2005. Gut erhalten - neu erforscht. Die Kreisgrabenanlage von Steinabrunn. In Daim, F., Neubauer, W., (dir.). Zeitreise Heldenberg. Geheimnisvolle Kreisgräben. Niederösterreichische Landesausstellung 2005. Katalog des NÖ Landesmuseums, Neue Folge Nr. 459, 61-69. 